\title{
Storage and Viability Testing of Protea Pollen
}

\author{
I. David van der Walt and Gail M. Littlejohn \\ Agricultural Research Council, Vegetable and Ornamental Plant Institute, Private Bag X1, Elsenburg \\ 7607, South Africa
}

Additional index words. in vitro germination, humidity control, liquid nitrogen, fluorochromatic test, pollination, pollen tubes

\begin{abstract}
The influence of storage temperature and humidity on pollen viability was studied in four Protea species. Pollen was stored at a range of temperatures and relative humidities for up to 1 year and tested for ability to germinate in vitro. Pollen of $P$. repens (L.) L. 'Sneyd', P eximia (Salisb. ex Knight) Fourcade 'Fiery Duchess' and $P$. magnifica Link. clone T 840705 stored at $-196^{\circ} \mathrm{C}$ and -14 to $-18^{\circ} \mathrm{C}$ retained a germination percentage as high as that of fresh pollen regardless of humidity. Humidity control became increasingly important at storage temperatures above $0{ }^{\circ} \mathrm{C}$. The study showed that long-term storage of Protea pollen is not feasible at temperatures above $0{ }^{\circ} \mathrm{C}$. The relationship between germinability and fluorochromasia (FCR) was studied during storage of 'Sneyd' pollen. The correlations between FCR and germinability were found to be low and nonsignificant. Fifteen-month-old cryopreserved 'Sneyd' pollen functioned in fertilization and seed set as effectively as fresh pollen.
\end{abstract}

Protea is the genus of most commercial importance of the South African wild-flower (fynbos) industry and has an annual export value of about R20 million. To meet the requirements of fashionconscious markets, systematic controlled breeding is essential to produce new cultivars.

Genetic improvement of Protea by breeding and selection is gaining momentum in a number of countries around the world. However, breeding has been limited by crossing incompatibility between species, lack of pollen storage techniques, and low hybrid seed set (Brits, 1992). Developing technology for long-term pollen storage would facilitate the crossing of species with differing flowering periods. In addition, stored pollen could have potential as long-term germplasm preservation, especially of unique genotypes.

Favorable conditions for pollen storage have been investigated for many agronomic and horticultural crops (Lee et al., 1985; Yates et al., 1991). In general, low temperature and low relative humidity maintain viability, but there are many exceptions (Stanley and Linskens, 1974). Viability of pollen from Proteaceae species was higher at $5{ }^{\circ} \mathrm{C}$ storage than $-10^{\circ} \mathrm{C}$. Viability could be maintained at $5{ }^{\circ} \mathrm{C}$ for at least 1 month (Shchori et al., 1992). Fresh Protea pollen has been viable for up to $6 \mathrm{~d}$ of storage at room temperature and up to 6 weeks at $5^{\circ} \mathrm{C}$ (Brits and Van den Berg, 1990). Banksia menziesii pollen viability decreased rapidly at ambient temperature and 90\% was inviable after $24 \mathrm{~h}$ (Ramsey and Vaughton, 1991). Our preliminary field investigations demonstrated that $P$. repens 'Sneyd' pollen had viability of up to $70 \%$ after $7 \mathrm{~d}$, but decreased to $18 \%$ after $9 \mathrm{~d}$. Storing pollen for long periods at -20 ${ }^{\circ} \mathrm{C}$ would be practical in that conventional and readily available freezers could be used for storage (Pinney and Polito, 1990). The purpose of this study was to develop a practical method, using inexpensive, commonly available supplies and equipment, of storing Protea pollen for 1 year or more with sufficient viability to be used in controlled hybridizations. Since the ultimate goal for a breeder using stored pollen is to obtain viable seeds, the ability of stored Protea pollen to effect seed set in controlled pollinations in the field was also investigated in this study.

Received for publication $15 \mathrm{Sept}$ 1995. Accepted for publication $29 \mathrm{Feb} 1996$. This paper is a revision of a chapter of a MS thesis submitted by I.D. van der Walt to satisfy the requirements in plant breeding at the Univ. of Stellenbosch. We thank Frikkie Calitz and Marieta van der Rijst for their assistance in statistical analyses. The cost of publishing this paper was defrayed in part by the payment of page charges. Under postal regulations, this paper therefore must be hereby marked advertisement solely to indicate this fact.

\section{Materials and Methods}

Pollen collection. Experiments were conducted from 1992 to 1994 on four species planted in experimental plantations at

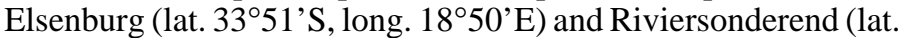
$34^{\circ} 08^{\prime}$ S, long. $19^{\circ} 54^{\prime} \mathrm{E}$ ) in South Africa. Before the experimental period, all plants had been subjected to routine plantation management practices, including drip-irrigation during the summer. Harvesting of blooms in previous years served as the only form of pruning of the bushes. For the storage experiments, pollen of $P$. magnifica clone T84 07 05, P. eximia 'Fiery Duchess', P. repens 'Sneyd', and P. aristata Phill 'Aristocrat' was used. Five inflorescences per plant from five plants, with about one-half of the florets having undergone anthesis, were harvested and brought to the laboratory where the stems were placed in water. All the open florets were removed, and $16 \mathrm{~h}$ later all florets that had subsequently opened were harvested (about 25/inflorescence). The pollen from each plant (five inflorescences) was scraped off, thoroughly mixed, and used as a single replicate. All replicates were first dried for $24 \mathrm{~h}$ in a desiccator over silica gel (blue) at $5{ }^{\circ} \mathrm{C}$, after which the pollen mixtures were divided into separate samples and placed in gelatine capsules for storage. The number of samples was large enough to ensure that each sample would be tested only once.

Pollen storage. The gelatine capsules with predried pollen samples were stored at room temperature $\left(22\right.$ to $\left.27^{\circ} \mathrm{C}\right)$, in a household refrigerator $\left(2\right.$ to $\left.7^{\circ} \mathrm{C}\right)$, in a household freezer $\left(-14\right.$ to $\left.-18^{\circ} \mathrm{C}\right)$, and in liquid nitrogen $\left(-196^{\circ} \mathrm{C}\right)$. At all the temperatures, except in liquid nitrogen, which has negligible water vapor pressure, the pollen samples were stored at relative humidities (RHs) of $10 \%, 30 \%$, and $60 \%$. Humidities were maintained with different concentrations of sulfuric acid (Solomon, 1951; Weast, 1988). The atmospheres were produced in closed 1000-mL flasks and were equilibrated for at least 1 month before use. The freezing points of solutions were below the temperatures to which they were exposed in the freezer. Pollen of $P$. repens 'Sneyd' was stored at an additional humidity of $0 \%$, maintained over silica gel (blue) in a desiccator. For storage at $-196{ }^{\circ} \mathrm{C}$, the predried pollen samples were individually placed in $5-\mathrm{cm}^{3}$ plastic cryovials, which were directly submerged in liquid nitrogen in a nitrogen storage vessel. No precooling or cryoprotectant was used to treat pollen before freezing.

Viability tests. As a control on storage procedures, each replicate was scored for in vitro pollen germinability before storage. Stored samples were thawed and rehydrated for $3 \mathrm{~h}$ at $25^{\circ} \mathrm{C}$ in a $100 \% \mathrm{RH}$ atmosphere chamber before testing with the hangingdrop technique of Van Tieghem (1869). Pollen stored at room 
temperature was tested for germinability every $15 \mathrm{~d}$, while the other treatments were tested after 30, 90, 180, 270, and $360 \mathrm{~d}$ of storage. The germination medium used in the storage experiments consisted of $0.4 \mathrm{M}$ sucrose, $100 \mathrm{mg} \cdot \mathrm{L}^{-1} \mathrm{H}_{3} \mathrm{BO}_{3}, 300 \mathrm{mg} \cdot \mathrm{L}^{-1}$ $\mathrm{Ca}\left(\mathrm{NO}_{3}\right)_{2} \cdot 4 \mathrm{H}_{2} \mathrm{O}, 20 \mathrm{mg} \cdot \mathrm{L}^{-1} \mathrm{MgSO}_{4} \cdot 7 \mathrm{H}_{2} \mathrm{O}$, and $100 \mathrm{mg} \cdot \mathrm{L}^{-1} \mathrm{KNO}_{3}$ in distilled water. The $\mathrm{pH}$ was adjusted to 7.0 using $0.1 \mathrm{M} \mathrm{HCl}$ or $\mathrm{KOH}$ solutions. Germination was scored after $3 \mathrm{~h}$ with an Olympus BH-2 light microscope at a magnification of 200x. At least 200 randomly selected pollen grains in four different fields (about 50/field) were scored for germination. Only pollen grains producing tubes longer than the grain diameter were scored as having germinated.

The in vitro germination test was compared with the fluorochromatic (FCR) test. Only stored pollen of P. repens 'Sneyd' was used for this purpose. The fluorochromatic (FCR) test procedure of Greissl (1989), using fluorescein-diacetatepropidium-iodide, was used. As a control, each pollen replicate was tested before storage with the FCR test procedure. Each stored pollen sample was divided into two subsamples, one being assayed for germination and the other using the FCR procedure at each of the testing times. Pollen grain fluorescence was determined with a Nikon Biophot microscope equipped with an episcopic-fluorescence attachment and a B-2A filter system consisting of a dichroic mirror $(510 \mathrm{~nm})$, a blue excitation filter (450 to $490 \mathrm{~nm})$, and a barrier filter $(520 \mathrm{~nm})$. All pollen grains which fluoresced brightly were scored as viable. Viability percentages were determined, using five replicates of about 200 grains each.

Viability of 15-month-old 'Sneyd' pollen stored in liquid nitrogen was tested further by pollination in the field, and the results were compared with those obtained with fresh pollen. The stored pollen was frozen and thawed once before this experiment. Thirty $P$. repens 'Sneyd' inflorescences, with about one-half of the florets having undergone anthesis, were labelled and all open florets were removed with scissors (Fuss and Sedgley, 1991). The inflorescences were covered with semi-rigid wire mesh cages $(2 \times 2$-mm apertures $)$ to exclude pollinators (Coetzee and Giliomee, 1985) and prevent contact between the florets and the pollination bag (Fuss and Sedgley, 1991). After $16 \mathrm{~h}$, the cages were removed and all remaining unopened florets were removed, leaving a ring of between 15 and 35 open florets. Self-pollen was not removed from these florets. The inflorescences were recaged until pollination at three days after anthesis.

Ten inflorescences were pollinated with fresh 'Sneyd' pollen (self-pollinated); ten inflorescences with 15-month-old liquid nitrogen-stored pollen; and ten inflorescences unpollinated as controls. Florets were pollinated in the morning by touching their stigmas with pollen presenters from newly opened donor florets, which had also been caged to prevent contamination, or by touching stigmas with 15-month-old liquid nitrogen-stored pollen. Stored pollen was rehydrated before pollination, as previously described. Three replicates (nine inflorescences) were harvested $7 \mathrm{~d}$ after pollination when penetration of the ovule had occurred. The bottom part of the pollinated pistils, including the ovary, were carefully dissected from the involucral receptacles, fixed in Carnoy's solution for $24 \mathrm{~h}$, and transferred to $70 \%$ ethanol for storage at room temperature. Before processing ovaries for fluorescence microscopy (Kho and Baër, 1968;
Martin, 1959), ovaries were transferred to $30 \%$ ethanol, washed in distilled water $(\times 3)$, softened for $30 \mathrm{~min}$ in $0.8 \mathrm{~N}$ sodium hydroxide at $75^{\circ} \mathrm{C}$, washed again in distilled water $(\times 3)$, and stained overnight in a $0.1 \%$ solution of water-soluble aniline blue dye in $0.1 \mathrm{~N}$ $\mathrm{K}_{3} \mathrm{PO}_{4} \cdot \mathrm{H}_{2} \mathrm{O}$. To observe pollen tubes, the ovaries were placed on a slide and the cover slip was gently pressed to spread the material. Fluorescing pollen tubes were observed by means of a Nikon Biophot microscope equipped with a episcopic-fluorescence attachment and a UV-2A filter system consisting of a dichroic mirror $(430 \mathrm{~nm})$, an ultraviolet excitation filter (380 to $425 \mathrm{~nm})$, and a barrier filter $(450 \mathrm{~nm})$. The number of pollen tubes in the ovary was recorded as well as the number of tubes that had penetrated the ovules. Seven replicates (21 infructescences) were harvested 7 months after pollination, when the achenes had matured (Van Staden, 1978), to record seed set for all the flowers pollinated previously. The infructescences were dried and the number of seeds per infructescence was recorded by dissecting the pollinated one-seeded achenes with a scalpel. The percentage seed set of pollinated florets per infructescence was calculated.

Statistical methods. The four species in the storage experiments were investigated in separate experiments. Each experiment consisted of five replications in randomized blocks with a three-factor factorial design for treatments. The fluorometry experiment consisted of five randomized blocks with a split-plot design for treatments. Pearson product-moment correlations were calculated to measure the strength of the linear relationship between FCR percentage and germinability for each storage treatment. The pollination experiment consisted of randomized blocks. Analysis of variance (ANOVA) was performed for each part of the experiment separately and Pearson product-moment correlations were calculated to measure the strength of the linear relationship between different variables connected with pollen tube growth. For all experiments, ANOVA was performed using SAS statistical

Fig. 1. The effect of 22 to $27^{\circ} \mathrm{C}$ storage at different relative humidities on pollen germination. (A) Protea repens 'Sneyd', (B) P. magnifica T84 07 05, (C) P. eximia 'Fiery Duchess', (D) P. aristata 'Aristocrat'.

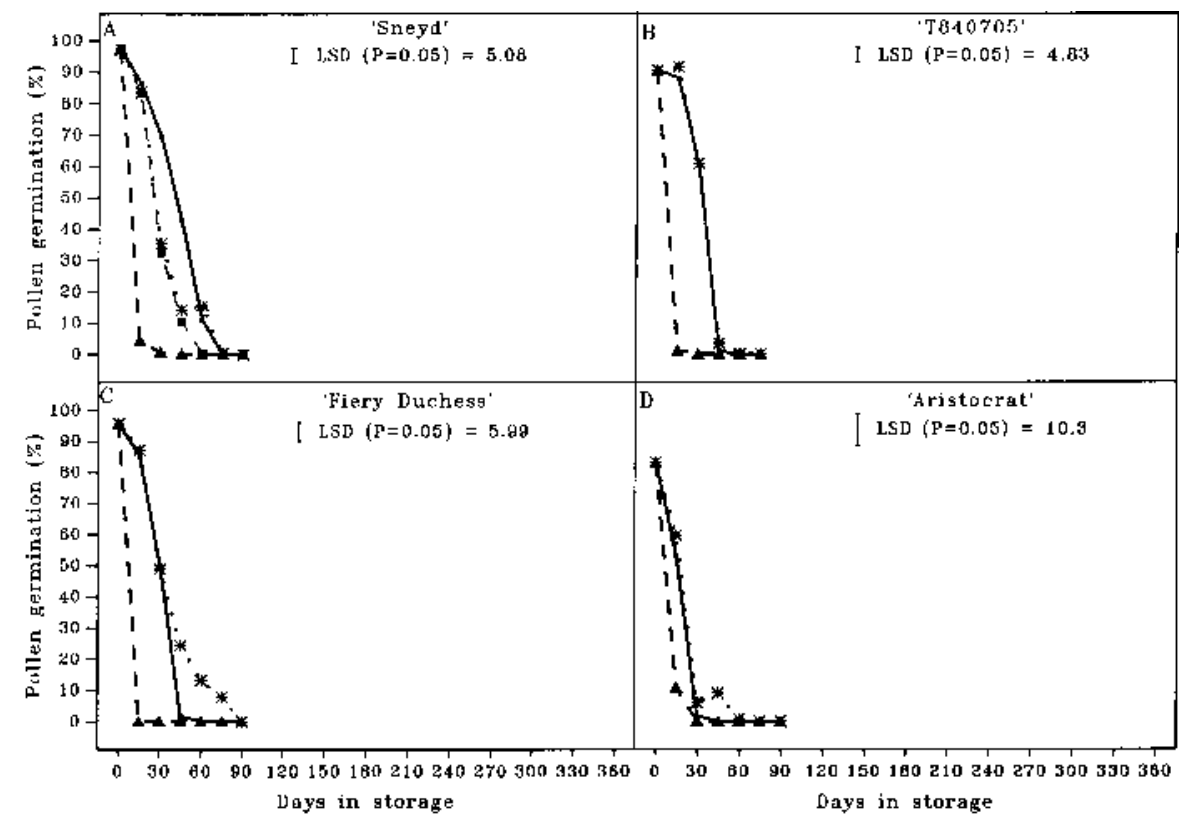

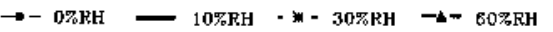




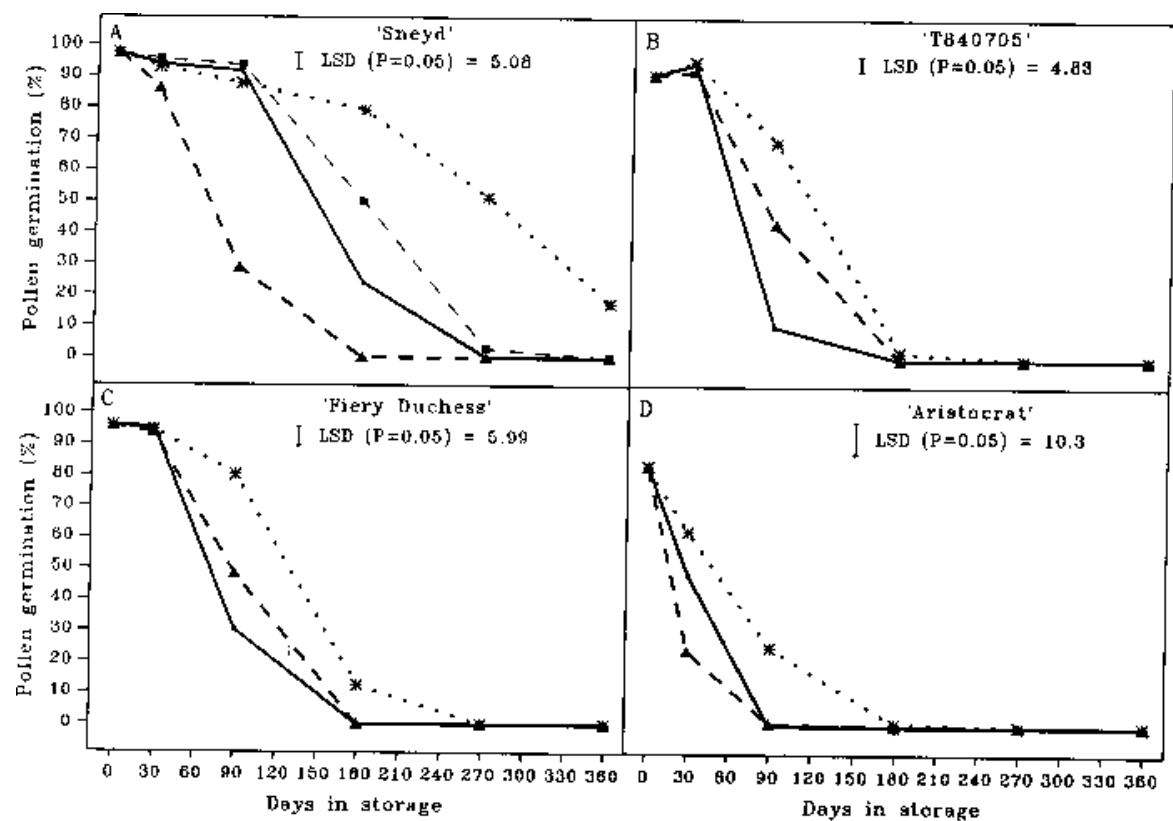

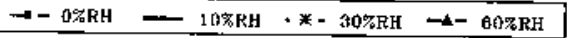

stored at 2 to $7^{\circ} \mathrm{C}$ was about three times longer than at 22 to $27^{\circ} \mathrm{C}$, regardless of humidity. At the optimum of $30 \% \mathrm{RH},>60 \%$ germination occurred after storage for $270 \mathrm{~d}$ for $P$. repens, $90 \mathrm{~d}$ for $P$. magnifica, $90 \mathrm{~d}$ for $P$. eximia, and $30 \mathrm{~d}$ for $P$. aristata (Figs. 2 A-D, respectively).

Pollen stored at -14 to $-18{ }^{\circ} \mathrm{C}$, only 'Aristocrat' showed a significant decline in germinability (50\% to $70 \%$ ) and differences between the RH treatments over the full length of time (Fig. 3). For this species, the $10 \%$ and $30 \% \mathrm{RH}$ treatments were significantly better than the $60 \% \mathrm{RH}$ after $360 \mathrm{~d}$. In addition, a significant increase in germinability occurred at $270 \mathrm{~d}$ compared to 90 and $180 \mathrm{~d}$ in the $10 \%$ and $30 \% \mathrm{RH}$ treatments; the reason for this is unclear.

Only 'Aristocrat' pollen showed a significant decline $(25 \%)$ in germinability after 360 days of storage at $-196^{\circ} \mathrm{C}$ (Fig. 4). An unexplained increase in germinability at $270 \mathrm{~d}$ compared to 90 and 180 d again occurred for this species (Fig. 4D).

Fluorometry. The fluorescence of pollen grains stained with the contrast-staining tech-

Fig. 2. The effect of 2 to $7{ }^{\circ} \mathrm{C}$ storage at different relative humidities on pollen germination. (A) Protea repens 'Sneyd', (B) P. magnifica T84 07 05, (C) P. eximia 'Fiery Duchess', (D) P. aristata 'Aristocrat'.

software version 6.08 (SAS Institute, Cary, N.C.). Student's least significant differences (LSD) were calculated at $P=0.05$ to compare treatment means. For all other effects in the ANOVA, $P=0.05$ was considered significant.

\section{Results}

In vitro germination. Pollen from four species of Protea had comparable responses to long-term storage conditions as determined by in vitro germination tests (Figs. 1 to 4 ). A significant three-factor interaction existed between method of pollen storage, $\mathrm{RH}$, and storage time for each pollen species. The main effects of the analysis could therefore not be interpreted independently. All four species tested showed a very high $(>80 \%)$ initial (fresh) germination percentage. The general response pattern of $P$. aristata pollen was similar to the other three species, but absolute germination percentages were lower for many treatments.

Pollen stored at 22 to $27^{\circ} \mathrm{C}$ was influenced significantly by RH (Fig. 1). Pollen germination was reduced to $<10 \%$ for pollen stored at $60 \% \mathrm{RH}$ within $30 \mathrm{~d}$ for all four species. Lower humidities maintained germination at $50 \%$ or higher for Protea species, except $P$. aristata, for this length of time. Regardless of humidity conditions, pollen stored at 22 to $27^{\circ} \mathrm{C}$ did not germinate after $90 \mathrm{~d}$ in any of the species.

Pollen stored at 2 to $7^{\circ} \mathrm{C}$, like pollen stored at 22 to $27^{\circ} \mathrm{C}$, had a significant response to $\mathrm{RH}$ (Fig. 2). However, pollen viability for pollen

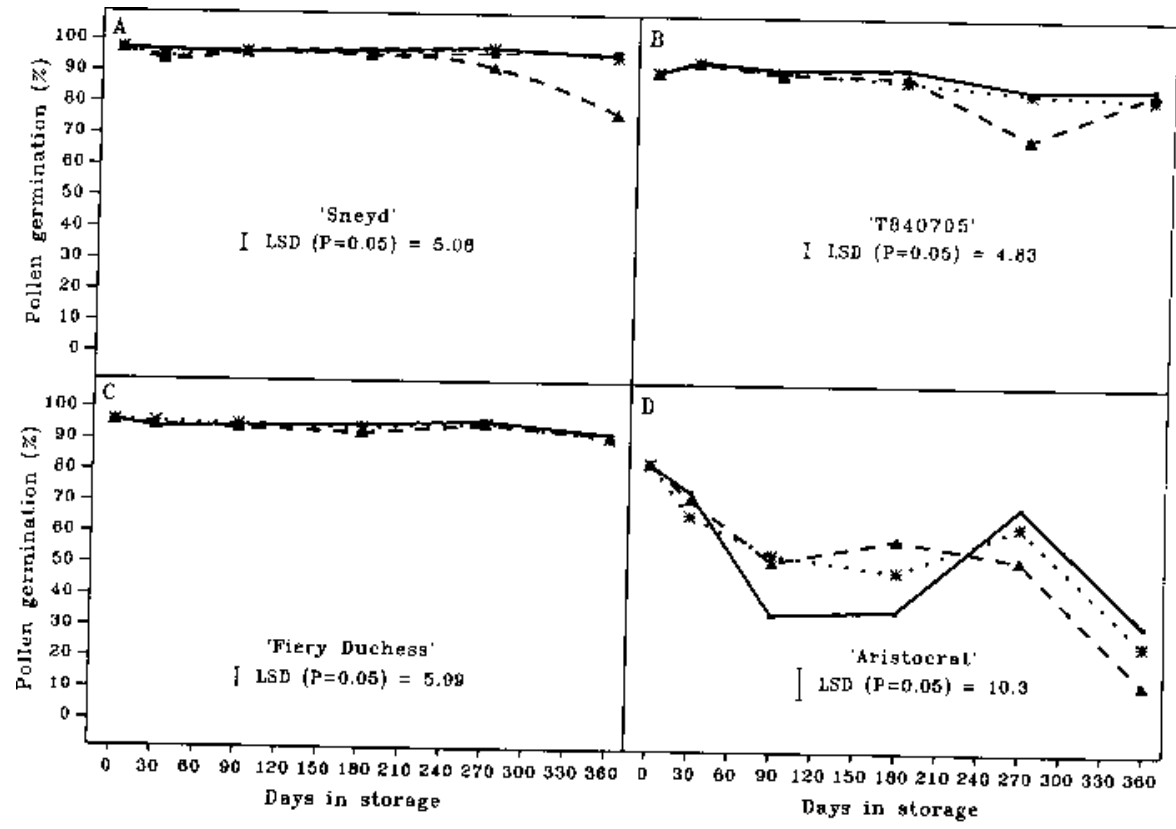

- - 0\%RH Ш $10 \% \mathrm{RH}$ - . 30\%RH 


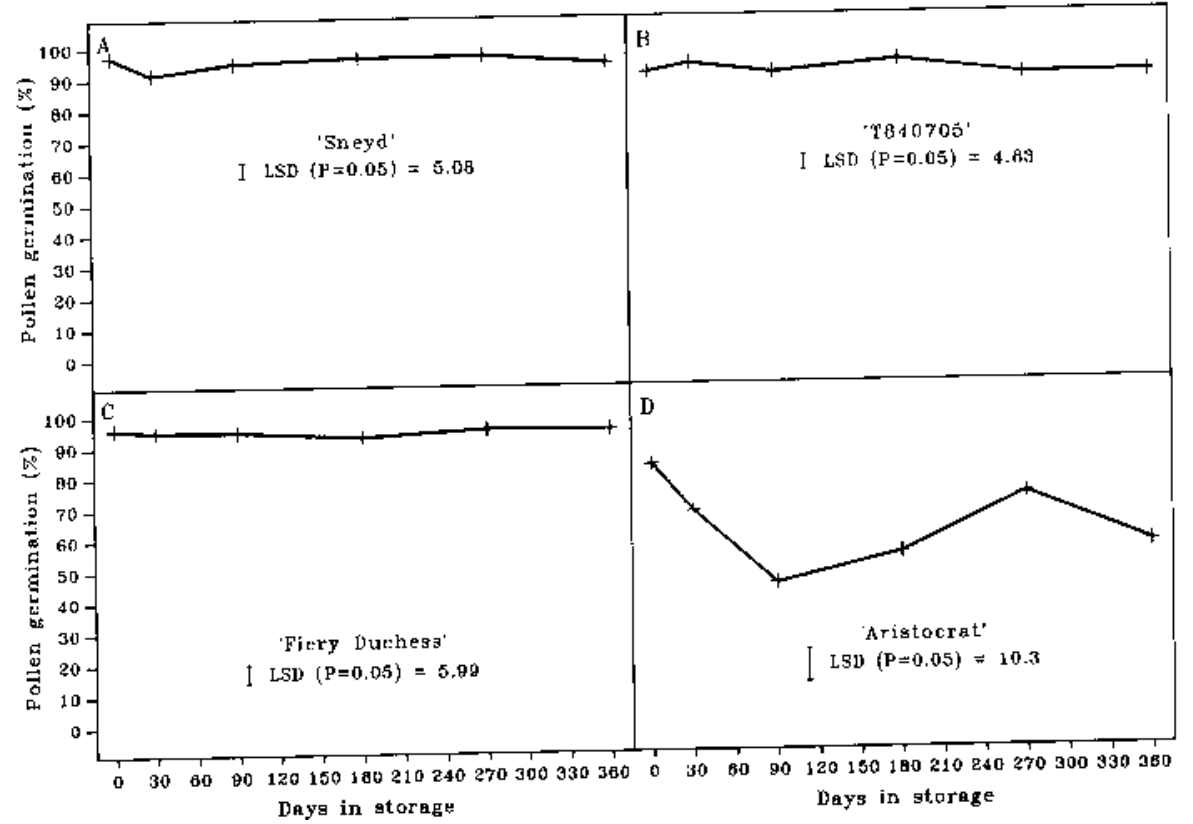

Fig. 4. The effect of $-196{ }^{\circ} \mathrm{C}$ storage on pollen germination. (A) Protea repens 'Sneyd', (B) P. magnifica T84 07 05,(C) P. eximia 'Fiery Duchess', (D) P. aristata 'Aristocrat'.

Correlation coefficients $(r)$ were low and nonsignificant, except for the $60 \% \mathrm{RH} 2$ to $7{ }^{\circ} \mathrm{C}$ treatment with $r=0.89(P<0.05)$.

Pollen stored at 22 to $27{ }^{\circ} \mathrm{C}$, as in the germination test, had a significant response to RH (Fig. 5A). At the optimum of $10 \% \mathrm{RH}$, almost $50 \%$ FRC capacity was retained after $90 \mathrm{~d}$ storage. As for viability as measured by germinability (Fig. 4A), FCR capacity was completely lost within $30 \mathrm{~d}$ under $60 \% \mathrm{RH}$. Contrary to the results obtained with the germination test with pollen stored at 2 to $7{ }^{\circ} \mathrm{C}$, the FCR test at this temperature indicated no significant differences or loss in viability for the different $\mathrm{RH}$ treatments, except at $60 \%$ RH after $360 \mathrm{~d}$ (Fig. 5B). At $60 \%$ RH pollen retained a FCR percentage exceeding $60 \%$ for only $120 \mathrm{~d}$ and was completely inviable after $270 \mathrm{~d}$. The FCR test further indicated that 'Sneyd' pollen retained a FCR percentage as high as that of fresh pollen after $360 \mathrm{~d}$ of storage, regardless of humidity, at -14 to -18 ${ }^{\circ} \mathrm{C}$ and $-196{ }^{\circ} \mathrm{C}$ (Fig. $5 \mathrm{C}$ and D).

Pollination. Controlled hand self-pollination of 'Sneyd' florets with pollen cryopreserved for 15 months resulted in a normal seed set $(80.2 \%)$, comparable to that derived from pollination with fresh pollen (75.3\%) (Fig. 6). Moreover, no significant differences were observed between cryopreserved and fresh pollen with regard to the percentage of florets containing pollen tubes, the percentage of florets with ovule penetration, and the mean number of pollen tubes per floret (Fig. 6). The control (unpollinated) differed highly significantly from the two hand-pollination treatments in all four of the variables tested. Correlation analysis between the three pollen tube variables indicated that correlation coefficients $(r)$ were strong and highly significant $(P<0.01)$.

\section{Discussion}

Protea pollen stored above $0{ }^{\circ} \mathrm{C}$ maintained viability for less than one year as reported for other genera (Ganeshan, 1985; Polito and Luza, 1988; Yates et al., 1991). Viability at temperatures above $0{ }^{\circ} \mathrm{C}$ declines rapidly, especially when the humidity of the storage atmosphere is not controlled (Luza cand Polito, 1985).

Controlling humidity at temperatures below $0{ }^{\circ} \mathrm{C}$ can have a marked effect on retention of pollen germinability for some plants (Allan, 1963; Hanna, 1990; Luza and Polito, 1985; Polito and Luza, 1988). However, controlling humidity below $0{ }^{\circ} \mathrm{C}$ had no advantage for many Protea species, similar to results with pear, apple, tomato and azalea (Visser, 1955). Our results provide evidence that Protea pollen may be stored relatively cheaply in a household freezer without humidity control for periods adequate for breeding purposes. Furthermore, satisfactory preservation of Protea pollen was obtained by cryotechnology simply by immersion into liquid nitrogen. Theoretically, pollen stored in liquid nitrogen should retain viability indefinitely (Stanley and Linskens, 1974), provided precautions are taken to reduce pollen moisture before storage (Yates et al, 1991).

Low germination of stored 'Aristocrat' pollen over all storage treatments suggests that extrapolation of pollen longevity results from one Protea species or clone to another could be unwarranted. Differences in pollen longevity among cultivars are known to occur (Parfitt and Almehdi, 1984). Therefore, more Protea species or clones should be tested before the results of this study can be applied to the entire genus.

The finding that the FCR test does not correlate well with the in vitro germination test indicates that this assay is not suitable for viability determinations of stored Protea pollen. Similar results have been reported by Widrlechner et al. (1983) for azaleas. Heslop-Harrison et al. (1984) experienced similar problems when the method was used on stored pollen. However, many other studies (e.g., Greissl, 1989; Jansson and Warrington, 1988; Pinney and Polito, 1990; Radicati di Brozolo et al. 1990) have shown that the FCR test can provide an excellent guide to pollen germinability in a number of different species. Inspection of our graphs indicates that germinability scores are always lower than the FCR scores except where they lie within the margins of error. According to

Table 1. Correlations between fluorochromasia (FCR) percentage and germination percentage in vitro based on the data sources used for the text figures listed.

\begin{tabular}{lccc}
\hline \hline \multicolumn{2}{c}{ Treatment } & & $\begin{array}{c}\text { Source } \\
\text { of data }\end{array}$ \\
\cline { 1 - 2 } Temp $\left({ }^{\circ} \mathrm{C}\right)$ & $\mathrm{RH}^{\mathrm{z}}(\%)$ & & $\begin{array}{c}r \\
(\mathrm{~N}=6)\end{array}$ \\
\hline 22 to 27 & 0 & Fig. 1A, 5A & $-0.42^{\mathrm{NS}}$ \\
& 10 & Fig. 1A, 5A & $-0.52^{\mathrm{NS}}$ \\
& 30 & Fig. 1A, 5A & $-0.55^{\mathrm{NS}}$ \\
& 60 & Fig. 1A, 5A & $-0.24^{\mathrm{NS}}$ \\
2 to 7 & 0 & Fig. 2A, 5B & $0.80^{\mathrm{NS}}$ \\
& 10 & Fig. 2A, 5B & $0.05^{\mathrm{NS}}$ \\
& 30 & Fig. 2A, 5B & $-0.45^{\mathrm{NS}}$ \\
-14 to -18 & 60 & Fig. 2A, 5B & $0.89^{*}$ \\
& 0 & Fig. 3A, 5C & $-0.16^{\mathrm{NS}}$ \\
& 10 & Fig. 3A, 5C & $-0.62^{\mathrm{NS}}$ \\
& 30 & Fig. 3A, 5C & $-0.77^{\mathrm{NS}}$ \\
-196 & 60 & Fig. 3A, 5C & $0.45^{\mathrm{NS}}$ \\
& -- & Fig 4A, 5D & $0.70^{\mathrm{NS}}$ \\
\hline
\end{tabular}

${ }^{\mathrm{z}} \mathrm{RH}=$ relative humidity.

Ns, ${ }^{*}$ Nonsignificant or significant at $P=0.05$, respectively. 


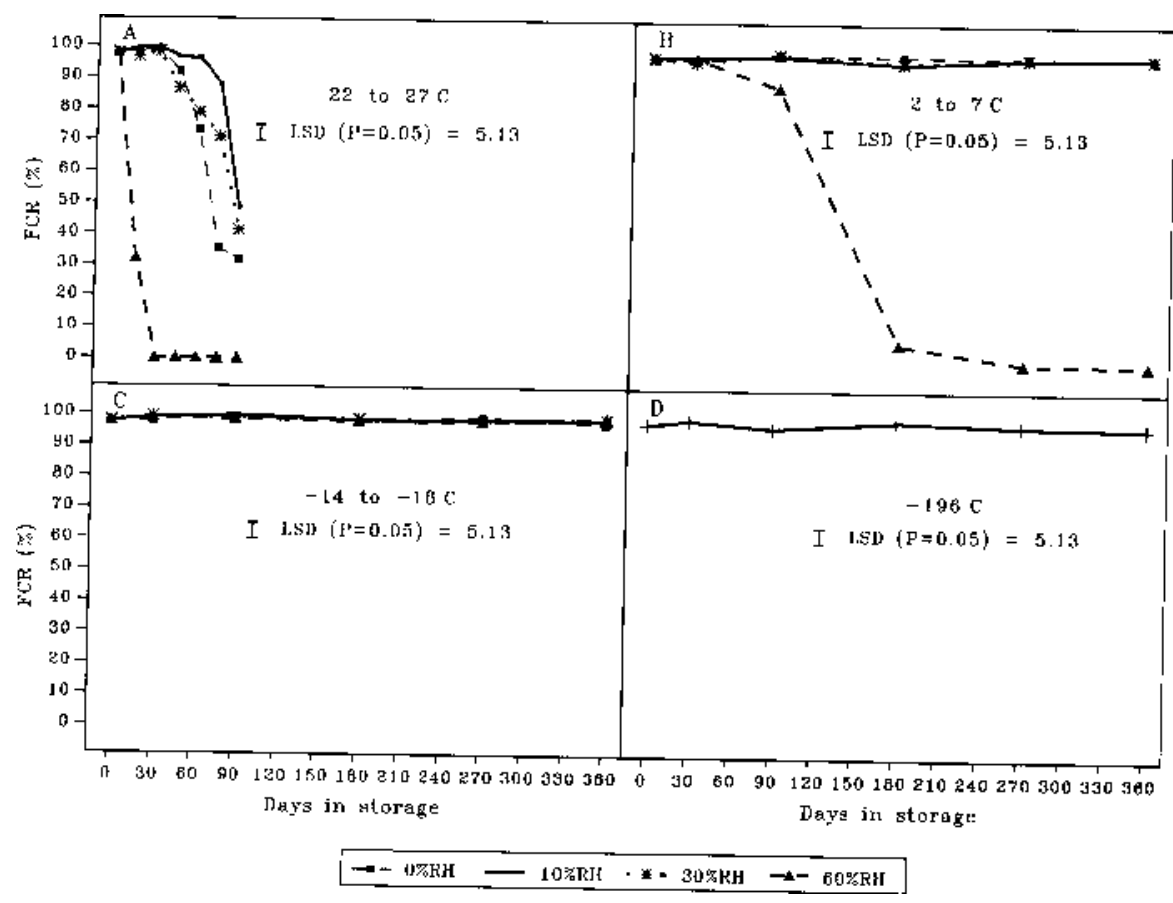

cryopreserved broccoli pollen germinated poorly (Crisp and Grout, 1984), and this should be investigated for Protea pollen as well.

In summary, freezer and liquid nitrogen storage can be successfully employed for the long-term storage of Protea pollen to assist breeding programs. Viability assessments of Protea pollen based on germination and the FCR are not correlated. In vitro germination is the most accurate and routine method for determining viability of Protea pollen held in long-term storage.

\section{Literature Cited}

Allan, P. 1963. Pollen studies in Carica papaya. II. Germination and storage of pollen. S. Afr. J. Agr. Sci. 6:613-624.

Bowes, S.A. 1990. Long-term storage of Narcissus anthers and pollen in liquid nitrogen. Euphytica 48:275-278.

Brits, G.J. 1992. Breeding programmes for Proteaceae cultivar development. Acta Hort. 316:918.

Brits, G.J. and G.C. van den Berg. 1990. Interspecific hybridization in Protea, Leucospermum and Leucadendron (Proteaceae). Proc. XXIII Intl. Hort. Congr. 1222.

Coetzee, J.H. and J.H. Giliomee. 1985. Insects in association with the inflorescence of Protea repens (L.) (Proteaceae) and their role in pollination. J. Entomol. Soc. S. Afr. 48:303-314.

Crisp, P. and B.W.W. Grout. 1984. Storage of broccoli pollen in liquid nitrogen. Euphytica 33:819-823.

Fuss, A.M. and M. Sedgley. 1991. The development of hybridization techniques for Banksia menziesii for cut flower production. J. Hort. Sci. 66:357-365.

Ganeshan, S. 1985. Cryogenic preservation of grape (Vitis vinifera L.) pollen. Vitis 24:169-173.

Ganeshan, S. 1986. Cryogenic preservation of papaya pollen. Sci. Hort. 28:65-70.

Ganeshan, S. and M.P. Alexander. 1990. Fertilizing ability of cryopreserved grape (Vitis vinifera L.) pollen. Vitis 29:145-150.

Greissl. R. 1989. Vitality analysis of monadic and polyadic pollen grains using optical contrast-fluorescence microscopy. Sci. Tech. Info. 9:180-184.

Griggs, W.H., H.I. Forde, B.T. Iwakiri, and R.N. Asay. 1971. Effect of subfreezing temperature on the viability of Persian walnut pollen. HortScience 6:235-237.

Hanna, W.W. 1990. Long-term storage of Pennisetum glaucum(L.) R. Br. pollen. Theor. Appl. Genet. 79:605-608.

Heslop-Harrison, J. and Y. Heslop-Harrison. 1970. Evaluation of pollen viability by enzymatically induced fluorescence; intracellular hydrolysis of fluorescein diacetate. Stain Technol. 45:115-120.

Heslop-Harrison, J., Y. Heslop-Harrison, and K.R. Shivanna. 1984. The evaluation of pollen quality, and a further appraisal of the fluorochromatic (FCR) test procedure. Theor. Appl. Genet. 67:367-375.

Jansson, D.M. and I.J. Warrington. 1988. The influence of temperature during floral development and germination in vitro on the germinability of kiwifruit pollen. N.Z. J. Expt. Agr. 16:225-230.

Kho, Y.O. and R.J. Baër. 1968. Observing pollen tubes by means of fluorescence. Euphytica 17:298-302.

Lee, C.W., J.C. Thomas, and S.L. Buchmann. 1985. Factors affecting in vitro germination and storage of jojoba pollen. J. Amer. Soc. Hort. Sci. 110:671-676.

Luza, J.G. and V.S. Polito. 1985. In vitro germination and storage of English walnut pollen. Sci. Hort. 27:303-316.

Marchant, R., J.B. Power, M.R. Davey, J.M. Chartier-Hollis, and P.T. Lynch. 1993. Cryopreservation of pollen from two rose cultivars. Euphytica 66:235-241.

Martin, F.W. 1959. Staining and observing pollen tubes in the style by
Protea repens 'Sneyd' pollen after hand pollination, measured by 1) percentag
Prontion of florets with pollen tubes, 2) percentage of ovules penetrated by a pollen tube, 3) percentage seed set, and 4) mean number of pollen tubes per floret. 
means of fluorescence. Stain Technol. 34:125-128.

Parfitt, D.E. and A.A. Almehdi. 1984. Liquid nitrogen storage of pollen from five cultivated Prunus species. HortScience 19:69-70.

Pinney, K. and V.S. Polito. 1990. Olive pollen storage and in vitro germination. Acta Hort. 286:207-210.

Polito, V.S. and J.G. Luza. 1988. Low temperature storage of pistachio pollen. Euphytica 39:265-269.

Radicati di Brozolo, L., G. Me, R. Vallania, and G. Vergano. 1990. Microsporogenesis, pollen germinability and viability in walnut cultivars with different blooming times: Methods and preliminary results. Adv. Hort. Sci. 4:139-143.

Ramsey, M., and G. Vaughton. 1991. Self-incompatibility, protandry, pollen production and pollen longevity in Banksia menziesii. Austral. J. Bot. 39:497-504.

Sedgley, M. 1981. Storage of avocado pollen. Euphytica 30:595-599.

Shchori, Y., T. Goren, and J. Ben-Jaacov. 1992. Pollen germination and storage in Banksia and some other Proteaceae plants. Acta Hort. 316:19-22.

Solomon, M.E. 1951. Control of humidity with potassium hydroxide, sulphuric acid, or other solutions. Bul. Entomol. Res. 42:543-554.
Stanley, R.G. and H.F. Linskens. 1974. Pollen: Biology, biochemistry and management. Springer-Verlag. New York.

Van Staden, J. 1978. Seed viability in Protea neriifolia. I. The effects of time of harvesting on seed viability. Agroplantae 10:65-67.

Van Tieghem, P.M. 1869. Recherches physiologiques sur la végétation libre du pollen et de l'ovule et sur la fécondation directe des plantes. Ann. Sci. Nat. Bot. 5:312-329.

Visser, T. 1955. Germination and storage of pollen. Meded. Lanb. Hogesch. Wageningen 55:1-68.

Weast, R.E. 1988. CRC handbook of chemistry and physics. 69th ed.. CRC Press, Boca Raton, Fla.

Widrlechner, M.P. H.M. Pellett, P.D. Ascher, and S.C. Fuhrman. 1983. In vivo pollen germination and vital staining in deciduous azaleas. HortScience 18:86:88.

Yates, I.E. and D. Sparks. 1990. Three-year-old pecan pollen retains fertility. J. Amer. Soc. Hort. Sci. 115:359-363.

Yates, I.E., D. Sparks, K. Connor, and L. Towill. 1991. Reducing pollen moisture simplifies long-term storage of pecan pollen. J. Amer. Soc. Hort. Sci. 116:430-434. 